\title{
Konsistensi Pemahaman Siswa SMA terhadap Konsep Hukum Newton untuk Representasi Berbeda
}

\author{
Nurhasnawati, I Komang Wherdhiana dan Amiruddin Kade \\ Anna.hasnawati@gmail.com \\ Program Studi Pendidikan Fisika FKIP Universitas Tadulako \\ Jl. Soekarno Hatta Km. 9 Kampus Bumi Tadulako Tondo Palu - Sulawesi Tengah
}

\begin{abstract}
Abstrak - Penelitian ini bertujuan untuk menganalisis tingkat konsistensi representasi pada siswa SMA Negeri 5 Palu terhadap konsep hukum Newton. Subjek penelitian ini adalah siswa kelas x semester genap SMA Negeri 5 Palu yang terdiri dari 27 siswa. Tes terdiri dari 3 teori dasar hukum Newton yaitu hukum I Newton , hukum II Newton dan hukum III Newton, tiap-tiap hukum terbagi atas 2 tema berbeda dan setiap tema dibuat 3 soal dengan representasi berbeda yaitu representasi verbal, grafik dan diagram sehingga jumlah soal keseluruhan adalah 18 butir soal. Data penelitian dianalisis melalui pendekatan deskriptif kualitatif. Skor hasil tes kemudian dikelompokkan menjadi 3 kategori yaitu kategori tinggi, sedang, dan rendah. Masing-masing dari kategori, diambil 2 siswa perwakilan untuk diwawancara guna menggali informasi yang lebih mendalam. Hasil penelitian menunjukkan bahwa tingkat konsistensi pemahaman siswa menghasilkan sebagian besar siswa tidak konsisten dalam mengerjakan soal multirepresentasi. Untuk siswa dengan kategori tinggi hanya mampu berada pada kategori kurang konsisten. Sedangkan untuk kategori sedang dan rendah berada pada kategori tidak konsisten.
\end{abstract}

Kata Kunci: konsistensi, pemahaman konsep, representasi, hukum newton.

\section{PENDAHULUAN}

Pentingnya pemahaman konsep dalam proses belajar mengajar sangat mempengaruhi sikap, keputusan dan cara-cara menyelesaikan masalah. Saat konsep digunakan dalam kegiatan mengajar dan belajar, konsep memiliki arti yang lebih tepat dan mengacu pada tata cara pengkategorian pengetahuan dan pengalaman dikategorisasikan [1].

Anggapan siswa terhadap materi pelajaran fisika yang terkesan sulit dan menakutkan bukan tanpa alasan karena sebagian besar siswa tidak memahami konsep. Proses pembelajaran yang cenderung berpusat pada guru dan berjalan satu arah sehingga proses pembelajaran menjadi pasif, dalam pembelajaran ini siswa yang cenderung belajar fisika dengan menghafal rumus tanpa memahami konsepnya sehingga menimbulkan anggapan bahwa fisika itu sulit dan membosankan [2]. Salah satu tujuan yang adalah siswa memiliki pemahaman konsep yang baik [3].

Salah satu indikator pemahaman konsep yang baik adalah ditandai dengan mengenali dan memanipulasi konsep dalam berbagai representasi pula. Siswa yang benar-benar memahami konsep akan mampu menyelesaikan beberapa masalah dengan konsep sama, meski konteks dan representasinya berbeda [4].

Proses pemecahan masalah yang sukses bergantung kepada keterampilan merepresentasi masalah seperti mengonstruksi dan menggunakan representasi matematik di dalam kata-kata, grafik, tabel dan persamaanpersamaan, penyelesaian dan manipulasi simbol. Dengan demikian dapat dinyatakan bahwa representasi dalam pembelajaran fisika dapat digunakan untuk meminimalisasi kesulitan siswa dalam belajar fisika [5].

Seiring dengan bertambahnya jenjang pendidikan yang ditempuh siswa, materi-materi pelajaran khususnya fisika secara bertahap diperdalam sesuai dengan perkembangan tingkat berfikir siswa maka dari itu materi akan diulang dan dikembangkan kembali disetiap jenjangnya. Misalkan pada jenjang SMA untuk materi gaya.

Konsistensi sebagai kemampuan siswa dalam menjawab soal berbeda yang melibatkan konsep yang sama. Siswa sering menggunakan pemahaman konsep yang benar dalam menjawab soal yang diberikan, tapi tidak menerapkan kembali konsep tersebut ketika konteks soal berubah [6].

Kekonsistensian akan membawa siswa ketingkat pemahaman yang lebih baik dalam melihat berbagai konsep-konsep fisika yang dituangkan dalam berbagai permasalahan. Mengukur kekonsistensian siswa dalam menginteprestasikan permasalahan fisika dengan multirepresentasi dapat dilakukan dengan menggunakan tes multirepresentasi. Tes multirepresentasi yang digunakan merupakan tes pilihan ganda, tes tersebut disajikan dalam bentuk permasalahan fisika yang tidak hanya dalam bentuk verbal saja ataupun matematis saja, tetapi juga dalam bentuk gambar, diagram, maupun grafik . Kemampuan 
menginterprestasikan berbagai representasi permasalahan akan memberikan kemudahan dalam menganalisis berbagai permasalahan dari semua sudut representasi.

Penelitian sebelumnya menunjukkan sebagian besar siswa SMA tidak memahami hubungan antara konsep dan representasi. Sebagai hasilnya, siswa bingung garis medan dengan jenis lain dari representasi, seperti vektor gaya, vektor kecepatan, dan lintasan [7].

Berdasarkan penjelasan tersebut, maka peneliti tertarik melakukan penelitian untuk mengetahui tingkat konsistensi pemahaman siswa mengenai suatu materi dengan menggunakan berbagai representasi. Materi yang digunakan dalam penelitian ini yaitu hukum Newton.

\section{II.METODE PENELITIAN}

Penelitian ini merupakan penelitian kualitatif yang datanya berupa fakta-fakta penelitian ini menggunakan metote penelitian deskriptif ditujukan untuk mendeskripsikan atau menggambarkan fenomena-fenomena yang ada, baik fenomena yang bersifat alamiah ataupun rekayasa manusia [8].

Subjek penelitian ini adalah siswa kelas X IPA SMA Negeri 5 Palu. Pemilihan responden wawancara sebanyak 6 orang dipilih berdasarkan tingkat pemahaman yang dimiliki siswa dengan kategori tinggi,sedang, rendah dapat diperoleh dari hasil tes pilihan ganda dengan menghitung nilai rata-rata dan standar deviasi.

Instrumen penelitian ini yakni soal tes multirepresentasi dalam bentuk tes pilihan ganda. Item tes yang digunakan mengadopsi dan mengadaptasi item tes yang digunakan penelitian lain [9].

Instrumen yang digunakan dalam penelitian ini telah dikembangkan oleh peneliti. Tes berbasis multirepresentasi merupakan tes pilihan ganda dengan 6 konteks (tema) yang berbeda mengenai Hukum Newton. Cakupan materi hukum Newton yang digunakan meliputi materi hukum I Newton, hukum II Newton dan hukum III Newton. Dari setiap hukum, diambil masingmasing 2 tema. Dari seriap tema tersebut dibuat menjadi 3 soal dengan konsep dan konteks yang dibuat semirip mungkin pada stemnya untuk setiap soal namun dengan representasi yang berbeda.

Jumlah tema yang diangkat sebagai konteks dasar penyusunan soal adalah 6 tema. Untuk masing-masing tema dibuat menjadi 3 butir soal multirepresentasi, sehingga jumlah soal terdiri dari 18 soal.
Distribusi butir-butri soal konsistensi konsep hukum Newton disajikan pada Tabel 1 :

\begin{tabular}{|c|c|c|c|c|c|}
\hline \multirow{2}{*}{$\begin{array}{l}\text { Hukum } \\
\text { Newton }\end{array}$} & & \multirow{2}{*}{ Tema } & \multicolumn{3}{|c|}{ Nomor Soal } \\
\hline & & & Verba & Grafik & $\begin{array}{l}\text { Diagr } \\
\text { am }\end{array}$ \\
\hline \multirow{6}{*}{$\begin{array}{l}\text { Hukum } \\
\text { Newton }\end{array}$} & $\begin{array}{l}\text { Hukum I } \\
\text { Newton }\end{array}$ & $\begin{array}{l}\text { Benda } \\
\text { Bergerak }\end{array}$ & 10 & 12 & 14 \\
\hline & & $\begin{array}{l}\text { Benda } \\
\text { Diam }\end{array}$ & 15 & 1 & 7 \\
\hline & $\begin{array}{l}\text { Hukum } \\
\text { II }\end{array}$ & $\begin{array}{l}\text { Perlambat } \\
\text { an }\end{array}$ & 9 & 16 & 3 \\
\hline & Newton & Kecepatan & 6 & 13 & 17 \\
\hline & Hukum II & Tabrakan & 5 & 18 & 11 \\
\hline & Newton & Dorongan & 2 & 8 & 4 \\
\hline
\end{tabular}

Wawancara ditujukan untuk mendapatkan informasi tentang konsistensi representasi konsep hukum Newton siswa. Wawancara kemudian didokumentasikan melalui buku catatan dan alat perekam suara. Wawancara dilakukan pada responden yang terpilih.

Data yang diperoleh melalui wawancara mendalam kemudian dinalisis. Untuk menentukan nilai dari hasil tes konsistensi konsep hukum Newton oleh siswa, maka digunakan penskoran untuk setiap tema soal yaitu,

1. 2 poin, (konsisten) apabila memilih jawaban yang sesuai untuk tiga soal dengan tema yang sama.

2. 1 poin, (kurang konsisten) bila hanya menjawab 2 jawaban yang sesuai dengan tema yang sama.

3. O poin, (tidak konsisten) bila hanya menjawab $\leq 1$ jawaban yang sesuai dari soal dengan tema yang sama.

Pemberian poin pada siswa dilakukan dengan pemeriksaan pertema (perkonteks) soal. Jadi untuk setiap 3 soal dengan representasi yang berbeda dengan konteks yang sama pemberian poinnya 0,1 atau 2 poin. Jadi untuk soal yang terdiri dari 6 tema (konteks) soal maka jumlah poin siswa terdiri dari 6 jumlah poin dengan poin maksimal 12 poin.

\section{HASIL DAN PEMBAHASAN}

\section{A. Hasil Penelitian}

Adapun deskripsi hasil analisis terhadap konsistensi representasi hukum Newton siswa adalah sebagai berikut.

Penentuan kategori tinggi, kategori sedang dan kategori rendah dilakukan terlebih dahulu dengan menghitung skor rata-rata dan standar deviasi, data hasil tes representasikemudian 
dikelompokkan menjadi tiga kategori yaitu kategori tinggi, kategori sedang dan kategori rendah. Skor rata-rata yang diperoleh adalah sebesar 6,85 atau $38,06 \%$ dan nilalai standar deviasi adalah 2,97. Hasil tersebut menunjukkan bahwa perolehan skor tes multirepresentasi berada pada kategori rendah, dengan kriteria pemahaman konsep yaitu sangat kurang paham..

Berdasarkan jawaban tes pemilihan responden yang berjumlah 18 nomor dipilih sebanyak 6 orang responden berdasarkan distribusi jawaban tes pemilihan responden siswa yakni :

1. Kategori tinggi; nilai $>(6,85+2,97)$ nilai $>$ 9,82

2. Kategori sedang; $(6,85-2,97 \leq$ nilai $\leq(6,85$ $+2,97)=3,88 \leq$ Nilai $\leq 9,82$

3. Kategori rendah; nilai $<(6,85-2,97)=3,88$

Data mengenai hasil jawaban siswa dan pengkategoriannya dapat dilihat pada Tabel 2 .

TABEL 2 HASIL JAWABAN SISWA

\begin{tabular}{cccc}
\hline No & Kode Responden & Skor & Kategori \\
\hline 1 & R-01 & 14 & Tinggi \\
2 & R-05 & 13 & Tinggi \\
3 & R-16 & 8 & Sedang \\
4 & $\mathrm{R}-25$ & 9 & Sedang \\
5 & $\mathrm{R}-21$ & 3 & Rendah \\
6 & $\mathrm{R}-22$ & 2 & Rendah \\
\hline
\end{tabular}

Rekapitulasi jumlah jawaban siswa berdasarkan tingkat pengkategorian tinggi, sedang dan rendah dari hasil tes konsistensi konsep hukum Newton disajikan pada Tabel 3.

TABEL 3 REKAPITULASI TINGKAT PENGKATEGORIAN TINGGI, SEDANG DAN RENDAH

\begin{tabular}{ccc}
\hline Kategori & Jumlah Siswa & Persentase \\
\hline Tinggi & 3 & $11,11 \%$ \\
Sedang & 21 & $77,78 \%$ \\
Rendah & 3 & $11,11 \%$ \\
\hline Jumlah & 27 & $100 \%$ \\
\hline
\end{tabular}

Rekapitulasi jawaban benar siswa berdasarkan format representasi dari soal tes disajikan dalam Tabel 4.

TABEL 4 REKAPITULASI JAWABAN BENAR SISWA SETIAP FORMAT REPRESENTASI

\begin{tabular}{cccc}
\hline No & Representasi & $\begin{array}{c}\text { Jumlah Jawaban } \\
\text { Benar }\end{array}$ & $\begin{array}{c}\text { Persentse } \\
\text { Jawaban } \\
\text { benar }\end{array}$ \\
\hline 1 & Verbal & 52 & $32,09 \%$ \\
2 & Grafik & 55 & $33,95 \%$ \\
3 & Diagram & 78 & $48,15 \%$ \\
\hline & Jumlah & 185 & $38,06 \%$ \\
\hline
\end{tabular}

Data mengenai hasil jawaban siswa untuk kategori konsisten, kurang konsisten dan tidak konsisten dapat dilihat pada Tabel 5 .

TABEL 5 HASIL JAWABAN KONSISTENSI SISWA

\begin{tabular}{|c|c|c|c|c|}
\hline No & $\begin{array}{c}\text { Kode } \\
\text { Responden }\end{array}$ & $\begin{array}{c}\text { Nilai } \\
\text { Rata- } \\
\text { rata }\end{array}$ & Level & $\begin{array}{c}\text { Kategori } \\
\text { Nilai }\end{array}$ \\
\hline 1 & R-01 & 1,33 & II & $\begin{array}{c}\text { Kurang } \\
\text { Konsisten }\end{array}$ \\
\hline 2 & R-05 & 1,33 & II & $\begin{array}{c}\text { Kurang } \\
\text { Konsisten }\end{array}$ \\
\hline 3 & $R-16$ & 0,33 & III & $\begin{array}{c}\text { Tidak } \\
\text { Konsisten }\end{array}$ \\
\hline 4 & $R-25$ & 0,67 & III & $\begin{array}{c}\text { Tidak } \\
\text { Konsisten }\end{array}$ \\
\hline 5 & $\mathrm{R}-21$ & 0,17 & III & $\begin{array}{c}\text { Tidak } \\
\text { Konsisten }\end{array}$ \\
\hline 6 & $R-22$ & 0 & III & $\begin{array}{c}\text { Tidak } \\
\text { Konsisten }\end{array}$ \\
\hline
\end{tabular}

\section{B. Pembahasan}

Berdasarkan penelitian telah diketahui bahwa tingkat konsistensi konsep hukum Newton yang dimiliki oleh siswa sangatlah beragam, siswa yang memiliki tingkat konsistensi konsep tertinggi dengan nilai poin 1,33 dari nilai ratarata poin maksimal 2,0. Sedangkan nilai poin terendah yang dimiliki oleh siswa adalah 0 . Ratarata dari nilai poin yang diperoleh dari keseluruhan siswa adalah 0,43, nilai ini menunjukkan bahwa hasil perolehan poin siswa terhadap konsistensi konsep hukum Newton tergolong rendah. Nilai ini juga, menunjukkan bahwa sebagian besar siswa tidak konsisten dalam mengerjakan soal multirepresentasi. Untuk siswa dengan nilai poin tertinggi hanya mampu berada pada level II atau kurang konsisten.

Adapun secara menyeluruh rata-rata persentase jawaban responden untuk setiap representasi yaitu untuk diagram memiliki nilai paling tinggi dari kecenderungan siswa dalam menjawab soal yaitu diagram sebesar $48,15 \%$, grafik sebesar $33,95 \%$ dan verbal sebesar $32.09 \%$. Sama halnya juga terjadi pada penelitian sebelumnya dengan hasil bahwa representasi diagram dengan persentase tertinggi sekitar 49,1\% [10].

Berdasarkan hasil ini pula dapat dikatakan bahwa masih banyak siswa tidak memiliki kemampuan menyelesaikan permasalahan fisika dengan representasi verbal,diagram maupun grafik. Hal ini tidak terlepas dari kebiasaan siswa pembelajaran disekolah yang cenderung menggunakan format matematis dalam menyelesaikan masalah fisika, sehingga ketika siswa dihadapkan pada representasi berbeda yang bukan matematis, sebagian besar siswa tidak dapat menyelesaikannya. 
Berdasarkan pada hasil wawancara Kebanyakan responden berpikir bahwa benda yang bergerak selalu memiliki gaya, termasuk benda yang bergerak dengan kecepatan konstan. Hal ini bertentangan dengan hukum I Newton yang menyebutkan bahwa setiap benda cenderung mempertahankan keadaannya, yaitu tetap diam atau tetap begerak dengan kecepatan konstan. $\Sigma \mathrm{F}=0$. Begitu pula Pada tema benda diam responden beranggapan pada gaya normal ataupun gaya berat, memiliki gaya lebih besar ataupun lebih kecil memberikan gaya, yang seharusnya agar benda tetap dalam keadaan diam kedua benda akan memberikan gaya yang sama besarnya.

Untuk tema perlambatan aggapan responden hanya terfokus bahwa besarnya gaya sebanding hanya dengan percepatan benda bukan berdasar pada besarnya gaya yang diberikan sebanding dengan besar perubahan kecepatan yang terjadi, sehingga ketika dihadapkan pada soal yang menyangkut pada perlambatan dan percepatan konstan, responden masih banyak menagalami kekeliruan. Responden menganggap percepatan dan kecepatan itu sama. Sementara untuk tema kecepatan dengan soal yang berkaitan dengan dengan hubungan antara gaya dengan besar kecepatan, .

Pada tema tabrakan responden selalu beranggapan bahwa pada saat tabrakan terjadi, benda yang memiliki kecepatan dan massa yang lebih besar memiliki gaya yang lebih besar pula. Konsep ini sesungguhnya bertentangan dengan hukum III Newton dimana gaya aksi = gaya reaksi atau $\mathrm{F}_{\mathrm{aksi}}=\mathrm{F}_{\text {reaksi }}$ yang seharusnya kedua benda akan memberikan gaya yang sama besarnya. Hal ini berlaku juga pada peristiwa dorongan, responden menganggap hanya benda yang mendorong yang lebih besar memberikan gaya, sedangkan yang didorong lebih kecil memberikan gaya.

Berdasarkan hasil wawancara pada siswa tepilih (responden) diatas, dalam mengerjakan soal tes konsistensi konsep hukum Newton responden masih belum mampu menggolongkan soal tes terhadap konsep dasar dari tes itu sendiri. Ketidakmampuan responden dalam menentukan konsep dasar yang berlaku pada soal mengakibatkan kesalahan mereka dalam menyelesaikan dan menjawab soal. Kebanyakan dari responden menjawab soal dengan hanya mengira-ngira.

Kemampuan responden dalam menjawab soal tes konsistensi yang rendah ini tidak terlepas dari hasil belajar siswa di sekolah mereka. Kebanyakan siswa masih belum paham benar dari konsep-konsep dasar hukum Newton, terlebih lagi penerapannya dalam menyelesaikan soal dengan konsep dasar yang benar. Contohcontoh soal yang diajarkan di sekolah juga masih tergolong monoton yang lebih mengandalkan matematis sehingga mengakibatkan siswa belum mampu menyelesaiakan permasalahan fisika dengan beragam representasi seperti verbal, grafik dan diagram.

Untuk meningkatkan pemahaman konsep fisika pada siswa dianjurkan membiasakan diri dalam mengerjakan soal-soal konsistensi representasi, dimana penggunaan berbagai macam representasi dalam pembelajaran akan lebih menunjang untuk penguatan dan peningkatan pemahaman konsep yang dimiliki oleh siswa itu sendiri.

\section{KESIMPULAN DAN SARAN}

\section{A. Kesimpulan}

Berdasarkan hasil analisis dan pengolahan data tes multirepresentasi dan wawancara yang diberikan kepada siswa, maka dapat disimpulkan bahwa :

1. Tingkat konsistensi representasi siswa kelas $X$ SMA Negeri 5 Palu tergolong rendah. Beberapa faktor yang mempengaruhi adalah : pada konsep tentang hukum I Newton kesalahan responden berpikir bahwa benda yang bergerak selalu memiliki gaya, termasuk benda yang bergerak dengan kecepatan konstan. Pada konsep tentang hukum II Newton responden masih menganggap percepatan dan kecepatan itu sama, pemahaman responden juga belum mampu berdasarkan pada besarnya gaya yang diberikan sebanding dengan besar perubahan kecepatan yang terjadi. Sedangkan pada konsep tentang hukum III Newton responden masih berpandangan bahwa pada saat tabrakan terjadi, benda yang memiliki massa dan kecepatan lebih besar memiliki gaya yang lebih besar pula dan pada peristiwa dorongan, menganggap bahwa hanya benda yang mendorong yang memberikan gaya.

2. Tingkat konsistensi pemahaman siswa berdasarkan kategori menghasilkan sebagian besar siswa tidak konsisten dalam mengerjakan soal multirepresentasi. Untuk siswa dengan nilai poin tertinggi hanya mampu berada pada level II atau kurang konsisten.

3. Representasi diagram memiliki nilai paling tinggi dari kecenderungan siswa dalam menjawab soal yaitu representasi diagram sebesar $48,15 \%$, representasi grafik sebesar $33,95 \%$ dan representasi verbal sebesar $32.09 \%$. 


\section{B. Saran}

Peneliti menganggap perlu untuk meneliti lebih jauh tentang pemahaman siswa SMA tentang hukum Newton per hukumnya. Penelitian ini penting untuk menelaah hukum Newton berapakah siswa paling banyak mengalami kesulitan.

\section{DAFTAR PUSTAKA}

[1] R.L. Arends. Learning to Teach (Belajar untuk Mengajar) edisi 7. Yogyakarta: Pustaka Pelajar. 2008.

[2] Fatmawati. Identifikasi Tingkat Konsistensi Representasi dan Pemahaman Konsep Mahasiswa pada Format Verbal Grafik dan Diagram dalam Memecahkan Masalah Hukum III Newton. Skripsi. Palu. Universitas Tadulako. 2016.

[3] E.D. Meltzer. "Relation between students problem-solving performance and representational format". Amerika Journal of Physics, vol.73, No.5, p.463, 2005.

[4[ D. Hestenes. (1997). "Modeling methodology for physics teachers, in the changing role of physics departments in modern universities". In Proceedings of the International
Conference on Undergraduate Physics Education, College Park. Diunduh dari http://modeling.asu.edu./ r\&e/Modeling Meth. [13 November 2016].

[5] Kartini. (2009). "Peranan representasi dalam pembelajaran matematika. Prosiding". FMIPA,UNRI. [28 Oktober 2016].

[6] N. Aisyah. "Konsistensi jawaban mahasiswa pada representasi dengan konteks soal yang berbeda". Skripsi. Palu. Universitas Tadulako, 2017.

[7] Y. Cao dan M. B. Bárbara. "High school student representations and understandings of electric fields". International Journal of Physical Review Physics Education Research, 2016.

[8] N. S. Sukmadinata. Metode Penelitian Pendidikan. Bandung. Remaja Rosdakarya. 2010.

[9] S. Hidayat. "Konsistensi Jawaban Mahasiswa dalam Format Representasi Verbal, Diagram dan Grafik tentang Hukum III Newton". Tesis pada Program Studi Pendidikan Sains Pascasarjana UNTAD Palu: tidak diterbitkan. 2013.

[10] W. A. Hasyim. Analisis Koherensi Konsep Hukum Newton pada Siswa Kelas X SMA Negeri 5 Palu. Skripsi. Palu. Universitas

2015. 